\title{
Universiteit
}

Leiden

The Netherlands

\section{Milk Banks Through the Lens of Muslim scholars: One Text in Two Contexts}

Ghaly, M.M.I.

\section{Citation}

Ghaly, M. M. I. (2011). Milk Banks Through the Lens of Muslim scholars: One Text in Two Contexts. Bioethics. Retrieved from https://hdl.handle.net/1887/16542

Version: $\quad$ Not Applicable (or Unknown)

License: $\quad$ Leiden University Non-exclusive license

Downloaded from: https://hdl.handle.net/1887/16542

Note: To cite this publication please use the final published version (if applicable). 


\title{
MILK BANKS THROUGH THE LENS OF MUSLIM SCHOLARS: ONE TEXT IN TWO CONTEXTS
}

\author{
MOHAMMED GHALY
}

\author{
Keywords \\ milk banking, \\ biomedical ethics, \\ Islamic law, \\ collective legal reasoning \\ (ijtihād jamā'î), \\ fatwa, \\ Islam in the West, \\ multiculturalism
}

\begin{abstract}
When Muslims thought of establishing milk banks, religious reservations were raised. These reservations were based on the concept that women's milk creates 'milk kinship' believed to impede marriage in Islamic Law. This type of kinship is, however, a distinctive phenomenon of Arab tradition and relatively unknown in Western cultures. This article is a pioneer study which fathoms out the contemporary discussions of Muslim scholars on this issue. The main focus here is a religious guideline (fatwa) issued in 1983, referred to in this article as 'one text', by the Egyptian scholar Yūsuf al-Qaradāwī who saw no religious problem in establishing or using these banks. After a number of introductory remarks on the 'Western' phenomenon of milk banks and the 'Islamic' phenomenon of 'milk kinship', this article analyses the fatwa of al-Qaradāwī 'one text' and investigates the 'two contexts' in which this fatwa was discussed, namely, the context of the Muslim world and that of Muslim minorities living in the West. The first context led to rejecting the fatwa and refusing to introduce the milk banking system in the Muslim world. The second context led to accepting this system and thus allowing Muslims living in the West to donate and receive milk from these banks. Besides its relevance to specialists in the fields of Islamic studies, anthropology and medical ethics, this article will also be helpful to physicians and nurses who deal with patients of Islamic background.
\end{abstract}

\section{INTRODUCTORY REMARKS}

\section{Introducing milk banks in the West}

The WHO's international code of marketing of breastmilk substitutes adopted in 1981 represents an important component of the global effort to protect breastfeeding. ${ }^{1}$ Breastfeeding has since become generally accepted as the optimal method of feeding infants. ${ }^{2}$

\footnotetext{
${ }^{1}$ World Health Organization. 1981. International Code of Marketing of Breast-milk Substitutes. Geneva: World Health Organization; Anthony Costello \& Harshpal S. Sachdev. Protecting Breast Feeding from Breast Milk Substitutes. Br Med J 1998; 316: 1103.

${ }^{2}$ Heather J. Hosea, Michelle C. Cicalo, Carol D. Holland \& Catherine J. Field. 2008. The Immunological Components of Human Milk. In Advances in Food and Nutrition Research. Vol. 54. Steve Taylor, ed. London: Academic Press.
}

However, due to the increasing difficulty of maintaining the services of wet nurses since the early 20 th century and the limitations of using artificial formula, lactating women were asked to express their surplus milk for use in feeding premature and ill babies. With the help of technological and hygienic improvements, the idea of collecting human milk evolved into a sophisticated system of operational milk banks. ${ }^{3}$ Observers record 1909 as the year which witnessed the first milk bank opened in Vienna, Austria.

Since then, the phenomenon of milk banking has witnessed different ups and downs throughout time. Early in the 20th century, milk banking blossomed and grew with increased use of donor milk for ill and premature infants. In 1943, the American Academy of Pediatrics (AAP)

\footnotetext{
${ }^{3}$ Frances Jones. History of North American Donor Milk Banking: One Hundred Years of Progress. J Hum Lact 2003; 19(3): 313.
}

Address for correspondence: Dr Mohammed Ghaly, Leiden University, Faculty of Humanities, Leiden Institute for Religious Studies, Matthias de Vrieshof 1, Postbox 9515, 2300 RA Leiden, The Netherlands. Email: m.ghaly@hum.leidenuniv.nl 
created guidelines for milk banks which are now enforced by the Human Milk Banking Association of North America. ${ }^{4}$

With the advent of AIDS in the mid 1980s, the number of milk banks shrank dramatically due to people's concern about possible infections. ${ }^{5}$ By the 1990s, with evidence of safety and increased research on the benefits of human milk, donor milk banks were again expanding globally. ${ }^{6}$ Different researchers have now enumerated the various benefits of the human milk banking system, both for newborn babies, especially the medical aspects, and also for mothers donating milk, in particular psychologically for those who have suffered the death of their own children. $^{7}$

Many developed countries around the world now either have established donor milk banks or are considering the establishment of such institutions. ${ }^{8}$ During the First International Congress of Human Milk Banks hosted by Brazil in 2001, it was reported that France has 18 milk banks and Brazil 154. ${ }^{9}$ Currently, there are 17 human milk banks in the UK supplying 50-60 neonatal units. ${ }^{10}$ However, it is clear that public and even professional awareness of the human milk banking system is far from being ideal. For instance, it is argued that the public and healthcare providers are not sufficiently informed about this system. Additionally, many professionals still express their fear that donated breast milk can transmit infections, such as HIV, although the donation process strictly addresses such concerns. ${ }^{11}$

Internal dynamics of Islamic Law: early schools of Islamic Law and contemporary religio-scientific institutions

The Muslim and Arab world has remained detached from the aforementioned developments and discussions on the human milk banking system, for two main reasons, namely, the availability of professional or nonprofessional wet nurses ${ }^{12}$ and Islamic legal reservations against human milk banks, which will be the focus of this

\footnotetext{
${ }^{4}$ Katie Woo \& Diane Spatz. Milk Donation: What Do You Know About It? MCN Am J Matern Child Nurs 2007; 3(32): 151.

5 Alan Lucas. Aids and Human Milk Bank Closure. The Lancet 1987; 329(8541): 1092-1093; Jones, op. cit. note 3.

${ }^{6}$ Jones, op. cit. note 3 .

7 Woo, op. cit. note 4, pp. 153-155.

${ }^{8}$ Jones, op. cit. note 3, p. 313; Woo, op. cit. note 4, pp. 151-153.

${ }^{9}$ Woo, op. cit. note 4, p. 151.

${ }^{10}$ Catherine A. Boyd, Maria A. Quigley \& Peter Brocklehurst. Donor Breast Milk Versus Infant Formula for Preterm Infants: Systematic Review and Meta-analysis. Arch Dis Child Fetal Neonatal Ed 2007; 92: F169.

${ }^{11}$ Woo, op. cit. note 4, pp. 150-153.

12 Avner Giladi. 1999. Infants, Parents and Wet Nurses: Medieval Islamic Views on Breastfeeding and Their Social Implications, Leiden: Brill.
}

article. Before embarking on details, preliminary notes on Islamic Law are in order so as to acquaint the reader with the background of these debates among contemporary Muslim scholars.

Four main Sunni Schools, in addition to two more schools in the Shi' $1 \overline{1}$ tradition, have gained the upper hand in Islamic Law and remain influential to this day.

The Hanafi school was the official school of law during the Ottoman Empire and remains prevalent up to this moment in countries such as Turkey, Pakistan and among Muslims in India. The Mālikī school is still dominant in many Islamic countries, especially Morocco, Algeria, Tunisia, Libya and in some parts of Egypt. The Shāfíi school prevails today in countries such as Egypt, Iraq, Malaysia and Indonesia. The Hanbali school is prevalent in Gulf countries, especially the Kingdom of Saudi Arabia. ${ }^{13}$

Other schools of Islamic Law appeared in history and sometimes still play a role in contemporary juristic discussions, but they are far less influential than the abovementioned four schools. The Zāhirī school serves as a clear example in this regard. This school reached its final shape at the hand of the Andalusian scholar Ibn Hazm (d. 1063). This school has no collective adherents or geographical centres in the Muslim and Arab world at the moment. However, the works of Ibn Hazm have remained important sources for modern specialists in Islamic jurisprudence. ${ }^{14}$

The Shī ${ }^{`} \overline{1}$ tradition of Islam also developed its own schools of law. The Ja'fari school is the school of law within Twelver Shī'ism. The great majority of the Shī'īs now follow this school, such as those living in Iran, Lebanon and Bahrain. The Ja'farī school is also often quoted in Sunni juristic sources, such as the juristic encyclopedia prepared in Egypt by a group of Muslim Sunni scholars. Within the Zaydī branch of Shī'ism, there is also the Zaydī school whose adherents exist now mainly in Yemen. ${ }^{15}$

\section{When both classical and contemporary opinions matter!}

At present, writings of early authorities in the aforementioned schools of law still play a crucial role and represent a starting point for contemporary Muslim scholars. However, the phenomenon of a strict affiliation to one of these schools, especially in the Sunni circles, is not as strong as it was in the past. Additionally, new issues, such

\footnotetext{
${ }^{13}$ Mohammed Ghaly. Physical and Spiritual Treatment of Disability in Islam: Perspectives of Early and Modern Jurists. Journal of Religion, Disability and Health 2008; 12(2): 107-108.

${ }^{14}$ Abdel-Magid Turki. 2003. Al-Zāhiriyya. The Encyclopaedia of Islam. Vol. 11. CD-ROM edn v. 1.0. Leiden: Brill: 394-397.

${ }^{15}$ Ghaly, op. cit. note 13: p. 108.
} 
as the case of milk banks, which did not exist in earlier times, forced contemporary jurists to introduce fresh and independent reasoning, known in the jurists' language as $i j t i h \bar{a}$. Because of the complexity of new issues to be addressed by Muslim jurists, the need for external advice from specialists in the biomedical sciences became inevitable. New religious-scientific institutions acknowledged this need and made use of well-known experts in these sciences. This collaboration between religious Muslim scholars and biomedical scientists to develop an Islamic bioethics is known in the field of Islamic studies as collective legal reasoning (ijtihād jam $\bar{a} \hat{\imath}) .{ }^{16}$ This type of $i j t i h \bar{a} d$ is practised within four main institutions.

Chronologically speaking, the first was the Islamic Fiqh Academy, established in 1977, which is affiliated with the Muslim World League and based in Mecca, Saudi Arabia. ${ }^{17}$ The second is the International Islamic Fiqh Academy, established in 1981, based in Jeddah, Saudi Arabia, and affiliated with the Organization of Islamic Conference. ${ }^{18}$ The third institution, which deals exclusively with biomedical ethical issues from an Islamic perspective is the Islamic Organization for Medical Sciences, established in 1984 and based in Kuwait. ${ }^{19}$ In contrast to the aforementioned three institutions, which work mainly on issues relevant to Muslims living in the Muslim and Arab world, the European Council for Fatwa and Research, established in 1997 and based in Dublin, Ireland, focuses on issues with specific relevance to Muslim minorities living in the West. This council is one of the main theorists and advocates of the modern trend within Islamic Law, which keeps in mind the particular position of Muslim minorities living in a nonMuslim context, known as 'Islamic Law for Muslim Minorities (Fiqh al-Aqalliyyāt)'. ${ }^{20}$

These four institutions are not working in separate worlds but in close cooperation with each other. They sometimes hold joint conferences and usually refer to each others' fatwas and resolutions. Comparing the list of the members of these four institutions, we also notice that some people are members of more than one institution. Religious and (Bio)ethical guidelines (fatwas) given by such institutions usually enjoy wide acceptance among the Muslim public. However, the issuers of such fatwas are still far from being a final court of appeal and thus can still be challenged or rejected by individual competent Muslim scholars.

\footnotetext{
${ }^{16}$ Ibid.

17 Sālih al-Marzūqī al-Baqmī. 2006. Al-Ta'rīf bi al-Majma' al-Fiqhī al-íslāmī bi Makka al-Mukarrama. 3rd edn. Mecca: Rābitat al-'̄̄lam al-Istāmī.

${ }^{18}$ http://www.fiqhacademy.org.sa/ [Accessed 21 June 2010].

$19 \mathrm{http}: / / \mathrm{www}$. islamset.com/ [Accessed 21 June 2010].

${ }^{20} \mathrm{http}: / /$ www.e-cfr.org/en/ [Accessed 21 June 2010].
}

\section{MILK BANKS IN THE ISLAMIC TRADITION}

When Soraya Altorki, professor of anthropology at the American University in Cairo, investigated this type of kinship in 1980, she called it 'An Unexplored Problem in the Ethnography of Marriage', referring to the feeble attention paid to this culturally distinctive phenomenon in Muslim societies. ${ }^{21}$ Thereafter, Milk kinship started to attract further fieldwork by different anthropologists in the West, demonstrating the importance of this kinship in the daily life of Muslims. ${ }^{22}$

Some of these studies argued that milk kinship is a peculiar Arab folk physiology of lactation, as it was related that the prohibition against marrying a fostersister had been common among Arabs in the pre-Islamic period. ${ }^{23}$ Other researchers tried to prove that this phenomenon is by no means uniquely Arab, as Peter Parkes wrote:

Its similar elaboration as an impediment to marriage in the canon law of several eastern Christian churches, and its parallels in the juridical expansion of spiritual kinship elsewhere in Christendom, demand its broader comprehension within a comparative historical anthropology of Eurasian adoptive kinship. ${ }^{24}$

Beyond the possible origin of this phenomenon, different researchers tried to fathom out the rationale behind this phenomenon; why would milk per se institute kinship that bars marriage? Some researchers traced this prohibition back to an Arab folk physiology of lactation which assumes milk to transfer male semen. Thus, they interpreted this 'in terms of a hitherto somatic scheme of male filiative substances transmitted by lactation' ${ }^{25}$ Others challenged this interpretation and stated that this phenomenon needs to be understood 'in terms of its attested usage as an institution of clientage in Islamic tributary states - as documented throughout Central Asia'. ${ }^{26}$ Identifying the 'logic' of this type of kinship is also a difficult task for contemporary Muslim scholars. In a question directed to a Shī'i scholar about the logic of 'milk kinship' in Islam, he replied, 'It is not possible to define the reason for this legislation. One must work with the legal rulings as they arise in the legal text.' Other scholars expressed their conviction that science itself would

\footnotetext{
${ }^{21}$ Soraya Altorki. Milk-Kinship in Arab Society: An Unexplored Problem in the Ethnography of Marriage. Ethnography 1980; 19(23): 233.

${ }_{22}$ Peter Parkes. Milk Kinship in Islam: Substance, Structure, History. Social Anthropology 2005; 13(3): 307.

${ }^{23}$ J. Chelhod, J. Schacht \& J. Burton. 2003. Radā'. Encyclopaedia of Islam. Vol. 8. CD-ROM edn. v. 1.0 Leiden: Brill: 361.

${ }^{24}$ Parkes, op. cit. note 22, p. 308.

${ }^{25}$ Ibid: 307 .

${ }^{26}$ Ibid.
} 
disclose one day that breastfeeding creates some bond which would then explain God's injunction. ${ }^{27}$

Because of the weirdness of milk kinship to Western cultures, as well as the vagueness of its logic, this phenomenon can be best approached within 'multiculturalism' where one would be open to notions prevalent in cultures other than one's own. In any case, juristic rulings about milk kinship in Islamic Law still have social relevance in the day-to-day life of Muslims. Below, we will pay more attention to these rulings, focusing mainly on points pertinent to milk banks.

\section{Discussions within Islamic Law}

Breastfeeding institutes in Islamic Law, under specific conditions, a type of elective and non-biogenic kinship relation known in Arabic as rid̄a $\bar{a}^{\prime}$ or radā (lit. suckling). This type of kinship falls under the category of permanent grounds which bar marriage in Islam. A boy breastfed by a woman other than his own mother will be prohibited from marrying the woman who breastfed him in addition to other relatives of her such as her mother, daughters and sisters. As for the wet nurse or foster mother, she is prohibited from marrying the nursling (foster son) and the children and grandchildren of the foster son. ${ }^{28}$

On the basis of a number of Qur'anic and Prophetic references, Muslim jurists elaborated further a number of conditions whose fulfilment constitutes a recognized milk-kinship which bars marriage. These conditions revolve around three main elements, known among Muslim jurists as the pillars of breastfeeding (ark $\bar{a} n$ al-rad $\left.\bar{a}^{c}\right)$, namely, (1) the wet nurse ( $\left.m u r d i^{\prime}\right),(2)$ the milk (laban) and (3) the nursling ( $\left.\operatorname{rad}^{`}\right)$.

\section{The wet nurse}

One of the points relevant to contemporary juristic discussions on milk banks is the identity of the wet nurse. For instance, does suckling from more than one wet nurse institute milk kinship with them all? In response, Muslim jurists opined that if more than one wet nurse fed the baby each with an equal amount of milk then kinship is instituted with them all. However, if the amount of the milk given by one of them considerably exceeds that of the other then kinship will be instituted with the former only. If these wet nurses cannot be identified, either

\footnotetext{
${ }^{27}$ Morgan Clarke. The Modernity of Milk Kinship. Social Anthropology 2007; 15(3): 301-302.

${ }^{28}$ Wizārat al-Awqāf wa al-Shu'ūn al-Islāmiyya bi al-Kuwayt. No date. Al-Maws ü'a al-Fiqhiyya. Vol. 22. Kuwait: Ministry of Endowments and Religious Affairs: 247-248; Sayed Sikander Shah. Fosterage as a Ground of Marital Prohibition in Islam and the Status of Human Milk Banks. Arab Law Quarterly 1994; 9(1): 3.
}

because they are too many to record or because their names are not known, then there is no kinship because the other party with whom kinship would be instituted is unknown. ${ }^{29}$

\section{The milk}

The milk must reach the baby's stomach. The majority of jurists did not differentiate between this milk getting into the stomach through suckling from the breast (mass), drinking from a cup or bottle (wajūr) or by pouring milk into the baby's nostrils $\left(s a^{\prime} \bar{u} t\right) .{ }^{30}$ However, according to the Ja'farī school within the Shî'ī tradition and a minority among the Sunnī jurists, only suckling from the breast directly institutes kinship. ${ }^{31}$ Concerning the amount of milk, the majority of jurists (Hanafīs, Mālikīs and an opinion within the Hanbali school) opined that a little milk institutes kinship, just as a larger quantity of milk does. Other jurists (Shāfi'iss and Hanbalīs) stipulated that the nursling must drink at least five times or sessions, and according to the Shīi 1 jurists of the Ja'farī school more than ten times or sessions, each of which is separate from the other, otherwise suckling will not institute kinship. ${ }^{32}$

\section{The nursling}

As far as the nursling is concerned, Sunni and Shī'i jurists stipulated that the baby should not be older than two years during the suckling period. ${ }^{33}$

\section{Social relevance}

Although they might seem hair-splitting, these juristic details have direct social relevance. They played an important role in the daily life of many Muslims in both early times and continue to do so today. Different ethnographers and social historians have written on the varied functions of milk-kinship in political and social practices of Muslims. ${ }^{34}$

As for modern times, Soraya Altorki has shown that Saudi Arabian society pays attention to these juristic rulings. She recounted how, in several cases on record, the relatives of prospective marriage partners who belonged to one extended family sought an official decree from religious authorities in Mecca on whether or not the marriage could be contracted. Multiple and cross-cutting

\footnotetext{
29 'Uthmān b. 'Alī al-Zayla'ī. No date. Tabyīn al-Haquàiq Sharh Kanz al-Daqa’’ iq. 2nd edn. Vol. 2. Beirut: Dār al-Kitāb al-Islāmī: 181.

${ }^{30}$ Wizārat, op. cit. note 28, vol. 22: p. 243.

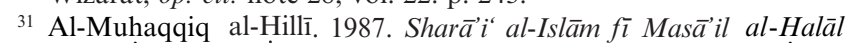
wa al-Häāam, Ismā'ilyān, Iran: Mu'assasat Matbū'ātī, vol. 2: 227.

${ }^{32}$ Ibid: 226; Wizārat, op. cit. note 28, vol. 22, p. 244.

33 Ibid: 227-228; Wizārat, op. cit. note 28, vol. 22, pp. 245-246.

${ }^{34}$ Clarke, op. cit. note 27, pp. 290, 292-293.
} 
milk relationships had confused the picture so much that they were unable to establish beyond doubt that a prohibiting rida $\bar{a}^{\prime} a$ [milk-kinship] link was not involved. ${ }^{35}$ She also added that cases of marriage contracted between two milk-relatives in violation of the religious prohibition are difficult to find, and where there are any, it is mostly because of ignorance rather than criminal intent. She mentioned a case where a married couple, being unaware of the milk-kinship between them, had children, three of whom were born with disabilities. After milk-kinship was discovered, the marriage was annulled and people interpreted the children's misery as divine punishment for violating the religious rules which prohibit their marriage ${ }^{36}$ Similar practices have been traced in Mauritanian society, especially among the Muslim Moors living in a region which has been Muslim for centuries. ${ }^{37}$ Anthropological studies on Shī'i Islam also prove the existence of such practice among Shī‘̄i Muslims. ${ }^{38}$

Recently, Morgan Clarke (Cambridge University) in the course of his fieldwork in Lebanon and Syria also elaborated on the relevance of milk kinship in the social life of contemporary Muslims. He referred to a number of recent fatwas published in different magazines read across the Arab world. These fatwas were issued by Muslim scholars in response to questions on milk kinship submitted by the readers of these magazines. ${ }^{39}$

\section{Milk banks and milk kinship}

On the basis of the above information, making use of the current system of human milk banks, Muslims would run the risk of committing 'incest' in the sense that a person who benefited from the donated milk might unknowingly marry one of his milk-relatives. The only way to avoid this risk is to create a database including the identity of the nursling and later on his children, the donating woman (foster mother) and her family including her husband. However, this database is not available in the current system of human milk banks in Western countries and it would be extremely difficult, if not impossible, to set up. This explains the resolution (fatwa) adopted by the International Islamic Fiqh Academy (IIFA) in its

\footnotetext{
35 Altorki, op. cit. note 21, p. 240.

${ }^{36}$ Ibid: 241-244. For further elaborations on the Islamic normative sources about disability as divine punishment, see Mohammed Ghaly. 2008. Islam and Disability: Perspectives in Islamic Theology and Jurisprudence, PhD diss., Leiden, the Netherlands: Leiden University: 77-83; Mohammed Ghaly. 2010. Islam and Disability: Perspectives in Theology and Jurisprudence. London: Routledge: 32-35, 42-49.

${ }^{37}$ Corinne Fortier. Blood, Sperm and the Embryo in Sunni Islam and in Mauritania: Milk Kinship, Descent and Medically Assisted Procreation. Body \& Society 2007; 13(3): 15-36.

38 J. Khatib-Chahidi. 1992. Milk-kinship in Shi'ite Islamic Iran. In The Anthropology of Breast-Feeding: Natural Law or Social Construct. V. Maher, ed. Oxford: Berg: 109-132.

${ }^{39}$ Clarke, op. cit. note 27, pp. 291-292.
}

second session held in December 1985; 'The establishment of milk banks should be prohibited in the Muslim world', adding that 'It is prohibited to feed a Muslim child from these banks'. ${ }^{40}$

This fatwa also accords with the social reality of Muslims living in the Muslim and Arab world, where so far not a single human milk bank has been established. The pioneering case of breast milk donation, to my knowledge also the sole one until now, which has been introduced in the neonatal intensive care unit at Adan Hospital in Kuwait, shows that the Islamic juristic rulings were taken into consideration. For instance, the religious implications of receiving donated milk were explained to the parties involved, who had to meet and know each other in person in addition to recording clear and detailed information about the amount of donated milk provided in order to satisfy religious conditions.$^{41}$ However, such procedures, as indicated by the doctor and expert on Islamic medical ethics, Hassan Hathout, makes establishing human milk banks practically impossible ${ }^{42}$ and put Muslims living in the West, where such banks already function without such procedures, in clear difficulties. For instance, it is related that a Muslim couple in Oxford refused steadfastly to feed their premature baby with the 'mixed' mothers' milk from the milk bank. Such a standpoint amazed those working in the hospital until one of the midwives involved heard about milk kinship and realized that parents did not want their child to become related through milk to women they did not know. ${ }^{43}$

Bearing in mind the difference in context between Muslims living in the Muslim and Arab world and those living as minorities in Western countries, the European Council for Fatwa and Research (ECFR) revised the aforementioned fatwa of the IIFA and came up with a new fatwa in its twelfth session held in January 2004, stating that making use of such milk banks, in case of need, does not raise religious problems in Islam, adding that using such milk does not institute milk-kinship which prohibits marriage in Islam. ${ }^{44}$ This change in opinion escaped the attention of the few modern researchers who tackled this point. ${ }^{45}$ Interestingly enough, the standpoint

\footnotetext{
${ }^{40}$ Mohamed Habib Ibn al-Khodja, ed. 2000. Resolutions and Recommendations of the Council of the Islamic Fiqh Academy, Jeddah: Islamic Development Bank \& Islamic Fiqh Academy: 10. For opinions of other individual scholars also prohibiting milk banks published in Arabic, see Giladi, op. cit. note 12, pp. 139-180.

${ }^{41}$ Niran A. al-Naqeeb, Ayman Azab, Mahmoud S. Eliwa \& Bothaina Y. Mohammed. The Introduction of Breast Milk Donation in a Muslim Country. J Hum Lact 2000; 16(4): 346-350.

42 Clarke, op. cit. note 27, p. 295.

${ }^{43}$ Khatib-Chahidi, op. cit. note 38, p. 128.

${ }^{44}$ Intifā‘ al-Atfāl min Laban Bunūk al-Halīb al-Qā’ima fī al-Gharb (Making use of Milk from Milk-banks in Western Mountries for [Muslim] Babies). Scientific Review of the European Council for Fatwa and Research 2004; 4-5: 463-464.

${ }^{45}$ Clarke, op. cit. note 27, p. 20; Fortier, op. cit. note 37.
} 
adopted by the IIFA as well as that of the ECFR have both been evoked by one paper or fatwa presented by the renowned contemporary scholar Yūsuf al-Qaradāwī to the two institutions. What did this fatwa say exactly about human milk-banks? Why did it lead to rejecting such banks in 1985 by the IIFA and accepting them by the ECFR in 2004? Such questions will be dealt with in Sections 3 and 4 below.

\section{ONE TEXT: THE FATWA IN FOCUS}

The Egyptian-born scholar, now based in Qatar, Yūsuf al-Qaradāwi $\overline{1},{ }^{46}$ received a question from a group of physicians affiliated with the Islamic Organization for Medical Sciences (IOMS). One of them is mentioned by name, viz., Hassan Hathout, a physician and specialist in medical ethics who has lived in the United States since 1989. ${ }^{47}$ According to al-Qaradāin̄, the question spoke about the dilemma of preterm babies whose health condition necessitates their stay in the hospital for several months during which they need milk, and for babies whose mothers die during delivery, so they also in their turn would miss their mothers' milk. The question goes on to state that, according to the specialist physicians, nothing is better than human milk which God has produced in the mothers' breasts as nutrition for newborn babies. Bearing this in mind, the question was, what is the religious ruling regarding establishing banks that will gather human milk in order to feed those babies? ${ }^{48}$

In response, al-Qaradāwī issued a detailed fatwa in which he handled the issue of establishing a human milk bank in view of the abovementioned juristic rulings concerning fosterage which might institute milk-kinship with its ensuing matrimonial prohibition. This fatwa was presented to three of the aforementioned institutions; first at the 1983 session on 'Islam and human reproduction' held by the IOMS, ${ }^{49}$ then at the second session held by the IIFA in 1985 which discussed the issue of 'milk banks' in a separate section ${ }^{50}$ and finally at the twelfth session held by the ECFR in 2004, which also dedicated a separate section to the discussion of this issue..$^{51}$ In addition, the fatwa was also published in the second volume of

\footnotetext{
${ }^{46}$ See Bettina Gräf. Sheikh Yūsuf Al-Qaradāwī in Cyberspace. Die Welt des Islams 2007; 47(3-4).

${ }^{47}$ See McDonnell Twair. 2008. Dr. Hassan Hathout: A Survivor of the 1948 Nakba and the Siege of Ramle. Washington Report on Middle East Affairs May-June: 26-27.

${ }^{48}$ Majallat Majma' al-Fiqh al-Islāmī. 1986; 2(1): 407.

49 Yūsuf al-Qaradāwī. 1983. Bunūk al-Halīb. In Nadwat al-Injāa fī Daw' al-Islām. 'Abd al-Rahmān al-'Awadī \& Aḥmad al-Jundī, ed. Kuwait: Islamic Organization for Medical Sciences: 50-57.

${ }^{50}$ Yūsuf al-Qaradāwī. Bunūk al-Halīb. Majallat Majma al-Fiqh al-Islāmī, 1986; 2(1): 385-390.

${ }^{51}$ Yūsuf al-Qaradāwī. Bunūk al-Laban (al-Halīb). Scientific Review of the European Council for Fatwa and Research 2005; 6: 15-22.
}

al-Qarad̄āwī's fatwa collection in a section entitled bayna $a l$-figh wa al-tibb (between Islamic Law and medicine), whose first edition appeared in $1993 .{ }^{52}$ Finally, the fatwa is available online via different websites such as the wellknown website www.islamonline.net. ${ }^{53}$

Al-Qarad̄āwī began his fatwa by commending the idea of human milk banks, stating that it has a noble aim which Islam advocates, namely, taking care of weak people especially when it concerns a helpless preterm baby.

Undoubtedly, every woman who donates some of her milk for the sake of feeding this type of baby deserves to be rewarded by God and thanked by people. It is even permissible to buy this milk from her if she does not donate it willingly, al-Qaradāwi $\overline{1}$ argued. He concluded his fatwa by opining that there is no barrier in Islam either to establish milk banks or to make use of them because such type of feeding does not institute kinship which prohibits marriage in Islam. ${ }^{54}$

Al-Qaraḍāwī based this opinion on three main arguments. First, the exact meaning of rad $\bar{a}^{r}$ (fosterage, lit. suckling) which institutes kinship. Quoting the Qur'anic verse which counts the set of relatives with whom one cannot marry, '. . . and your mothers who have suckled you and your foster sisters' [Sürat al-Nisä' 04:23], Concerning 'mothers', al-Qaradāwī infers that the Qur'anic verse speaks about 'motherhood', something which cannot be constituted just by consuming woman's milk anyhow but only by suckling and being in close touch with her breast, a practice which reveals the tenderness of motherhood and the passionate attachment of sonship. Only on the basis of this motherhood, other types of kinship originate, such as foster brotherhood. As for 'suckled', he argues that the Lawgiver (God) uses exclusively the term 'suckling ( $\mathrm{rad}_{\bar{a}}$ )' and its derivatives. The meaning of these words in the Arabic language, the language of the Qur'ān and the Sunna, is unequivocal, viz., breastfeeding and suckling and not just using milk as nutrition in whatever way. Keeping in mind that there is no real 'suckling' or direct 'breastfeeding' but just 'bottlefeeding' in the case of milk banks, al-Qaradāwī concludes that this practice cannot institute kinship. In this regard, al-Qaradāwī clearly deviates from the majority of Sunni jurists who opine that suckling or any other type of milk transmission institutes kinship. He is rather inclined towards the opinion adopted by a minority of jurists, although with recognized juristic authorities, including

\footnotetext{
${ }^{52}$ Yūsuf al-Qaradāwī. 1994. Fatāwā Múāsira. vol. 2, Kuwait: Dār al-Qalam li al-Nashr wa al-Tawzi' : 550-556).

${ }^{53}$ Yūsuf al-Qaradāwī. 2001. Bun ūk al-Halīb wa al-Tahrīm bi al-Radā ${ }^{c}$ Available at http://www.islamonline.net/servlet/Satellite?pagename= IslamOnline-Arabic-Ask_Scholar/FatwaA/FatwaA\&cid= 1122528600968 [Accessed 31 Jul 2008].

${ }^{54}$ Qaradāwīi, op. cit. note 51, pp. 16 \& 21.
} 
al-Layth Ibn Sa'd (d. 791), and the Zāhirī (literalist) jurist Ibn Hazm (d. 1063). ${ }^{55}$

The second argument is the unknowable identity (jahāla) of the women donating milk and the exact amount of such milk given to the baby. Within the system of milk banks, there is no system recording information about the donating women nor about the exact amount of milk given to each baby. On this point, al-Qaradāwi comes closer to the majority of jurists who opine that in case of doubtfulness (shakk) about the number of suckling-sessions or about the identity of the wet nurse, there would be no kinship. In support of his argument, al-Qaradāwī quoted well-known juristic sources within the Hanafì and Hanbali schools of law. ${ }^{56}$

The third argument appears in the concluding paragraph of the fatwa, in which al-Qaraḍāwi tried to answer a possible question that could be raised against his fatwa, viz., 'As long as establishing or using milk banks is a controversial issue, why do not we take the safe side [sic] and on grounds of caution prohibit it?' This question raises the ancient disagreement among Muslim jurists on the optimal method for dealing with controversial issues on which there is no clear ruling in the primary sources of Islamic Law (Qur'ān and Sunna) and thus space for various juristic opinions; should it be 'adopting the more cautious (al-akhdh bi al-ahwat)' and or 'adopting the more lenient (al-akhdh bi al-aysar)'? In the case under discussion, 'adopting the more cautious' would mean prohibiting milk banks whereas the latter method would lead to permitting them. Thus, al-Qaraḍ̄ $\overline{1} \overline{1}$ answers this question by saying that 'adopting the more cautious' is more fitting in private matters when the case concerns the person himself whereas 'adopting the more lenient' is more relevant to public affairs when it concerns a group of people or community at large; and milk banks fall under the category of public affairs. In keeping with the spirit of Islam, which is mainly based on 'lenience, easiness (yusr)' and also the nature of the modern time whose complications make people feel a dire need for this 'lenience', al-Qaradāwī favours 'adopting the more lenient' and thus declares the permissibility of establishing human milk banks, donating milk to them and receiving milk from them. ${ }^{57}$

\section{TWO CONTEXTS}

\section{First context: opposition in the Muslim and Arab world}

The main opponents of al-Qaradāwī's fatwa came from Muslim scholars participating in the 1983 session on

\footnotetext{
${ }^{55}$ Ibid: $17-20$.

${ }^{56}$ Ibid: $20-21$.

${ }^{57}$ Ibid: $21-22$.
}

'human reproduction in Islam ' held by the IOMS, and the second session of the IIFA held in 1985. After the fatwa was first presented during the 1983 session of IOMS, at least eleven scholars, eight ${ }^{58}$ from those participating in the session and another three ${ }^{59}$ who wrote against the fatwa later on, opposed the fatwa in different tones. ${ }^{60}$ During the 1985 session of the IIFA, the fatwa received at least ten opponents; nine ${ }^{61}$ from those who participated in the discussions during the session ${ }^{62}$ in addition to the Professor of Islamic Law in Qatar University, who is also member of both the the IIFA and the ECFR, 'Alī al-Qaradāghī. ${ }^{63}$ Worthy of mention in this regard is the physician Muhammad 'Alī al-Bār (consultant of Islamic medicine at the King Fahd Center for Medical Research \& King 'Abd al-'Azīz University, Jeddah). Al-Bār submitted a paper entitled, 'Bun $\bar{u} k$ al-Halīb (Milk banks)' to the 1985 session of the IIFA $^{64}$ which was also published later in a separate book. ${ }^{65}$ Al-Bār's paper outlined a historical background of milk banks in the United States and Europe. He explained that milk banks originated in the West and in the 1980s suffered a real decline in the United States. He also enumerated in detail the main medical, social and religious disadvantages of establishing milk banks in the Muslim and Arab world. These disadvantages were extensively used, as shown below, by the religious scholars who opposed al-Qaradāwī's fatwa. ${ }^{66}$ The main objections raised against the fatwa can be summed up in the following points:

The first objection was directed against discussing this issue in principle because of its irrelevance to the Muslim

\footnotetext{
${ }^{58}$ They are Badr al-Mutwallī 'Abd al-Bāsit (head of the Juristic Encyclopedia in Kuwait), Muhammad al-Ashqar (expert affiliated with the Juristic Encyclopedia in Kuwait), Ibrāhīm al-Dusūqī (Minister of Religious Endowment [Awqāf], Egypt), 'Umar al-Ashqar (Professor in the Faculty of Sharī'a, Kuwait), 'Izz al-Dīn Tūnī (researcher affiliated to the Juristic Encyclopedia in Kuwait), 'Abd al-Rahmān 'Abd al-Khāliq (Ministry of Education, Kuwait) Zakariyya al-Birrī (advisor of Kuwait Finance House) and Bakr Abū Zayd (head of the International Islamic Fiqh Academy).

59 They are 'Abd al-Rahmān al-Najjār (one of the Scholars of al-Azhar, Egypt), Muhammad Husām al-Dīn (the director of the office of the grand Imam of al-Azhar) and Muhammad Ahmad al-Shātirī (Saudi Arabia).

${ }^{60}$ Muhammad 'Alī al-Bār. Bunūk al-Halīb. Majallat Majma' al-Fiqh al-Islämī. 1986; 2(1): $404-405$.

${ }^{61}$ They are 'Abd Allāh al-Bassām (Saudi Arabia), Taqiyy al-'Uthmān̄̄ (Pakistan), Muhammad 'Abdu 'Umar (Yemen), 'Abd al-'Azīz 'Īsā (Egypt), al-Mukhtār al-Sulāmī (Tunis), 'Abd al-Halīm al-Jundī (Egypt) and Rajab al-Tamīmī (Palestine), in addition to Muhammad 'Alī al-Bār (Saudi Arabia).

62 Majallat, op. cit. note 48, pp. 414-423.

${ }^{63}$ 'Alī al-Qaradāghī. 2006. Bunūk al-Halīb. In Fiqh al-Qadāya al-Tibbiyya al-Mu'āsira. 'Alī al-Qaradāghī \& 'Alī Ỳūsuf al-Muhammad̄̄, ed. Beirut: Dār al-Bashā’ir al-Islāmiyya: 446-474.

${ }^{64}$ Bār, op. cit. note 60 , pp. 391-406.

${ }^{65}$ Ibid: $347-363$.

${ }^{66}$ Ibid: $391-406$.
} 
and Arab world. Basing themselves on the paper of al-Bār, a number of the opponents stressed that milk banks originated as a Western idea in a cultural and social context considerably different from that of the Muslim and Arab world. Newborn babies who need human milk, the opponents argued, always manage to find such milk in the Muslim and Arab world through wet nurses or through other lactating mothers within the family or neighbourhood. One of the opponents even suggested using cows' milk or herbs such as caraway as alternatives instead of establishing human milk banks. Again basing their argument on al-Bār's paper, they said that even in the West the idea is no longer thriving. Further, al-Bār stressed that establishing human milk banks in developing countries would be much more problematic because these countries are technologically less developed and thus run the risk of having non-hygienic or disease-transmitting banks. In any case, the opponents concluded, because the social structure and cultural context in the Muslim world differ from those of the West, there is no need to establish such banks nor even to discuss this idea from an Islamic perspective. ${ }^{67}$

The second objection was a response to al-Qaradāwî̀s first argument concerning the exact meaning of $\mathrm{rad}^{\mathrm{a}}$. The main argument of the opponents was that al-Qaradāwī deviated from the overwhelming majority of Muslim jurists within the four Sunni schools who state that a woman's milk transmitted in any mode, suckling, bottle-feeding, pouring in the throat or in the nostrils, to the stomach of the baby, institutes kinship which bars marriage. They also quoted a Prophetic tradition from which they inferred that $\mathrm{rad}_{\bar{a}} a$ was used to mean drinking a woman's milk from a bottle and not confined to direct suckling. ${ }^{68}$

The third objection is again a response to al-Qaradāwî̀'s second argument that if neither the identity of the donating woman nor the amount of milk given to the baby is known, then this fosterage does not institute kinship according to the majority of jurists. Opponents did not question the credibility of this opinion but counter-argued that this opinion can be used if the case of the doubtfulness (shakk) about the donating woman or the amount of milk already exists. Fortunately, they added, such banks do not exist at the moment. 'Why should we establish them in order to create doubtfulness by ourselves and then argue that in case of doubtfulness, fosterage does not institute kinship?' they wondered. To sum up, the case of doubtfulness does not exist yet and there is no need to bring it into existence. ${ }^{69}$

\footnotetext{
${ }^{67}$ Majallat, op. cit. note 48, pp. 394 422; Qaradāghī, op. cit. note 63, pp. 466-471.

${ }_{68}$ Majallat, op. cit. note 48, pp. 414 423; Qaradāghī, op. cit. note 63, pp. 472-473.

${ }_{69}$ Majallat, op. cit. note 48, pp. 414-417.
}

The fourth argument is also a response to al-Qaradāwī's third argument that in the case of milk banks, the method of 'adopting the more lenient (alakhdh bi al-aysar)' is the most suitable one. In support of his counterargument, al-Qaradāghī quoted a Prophetic tradition relating that a black woman came to a married couple and claimed that she had suckled both of them, which meant that marriage must come to an end because they were foster brother and sister. The husband accused her of being a liar and went to the Prophet Muhammad complaining to him about this woman. The Prophet's advice to the husband was to divorce his wife because of the woman's claim. Al-Qaradāghī commented on this tradition by saying that such authentic traditions indicate that rulings in this regard should be based on 'adopting the more cautious' approach. ${ }^{70}$ Another opponent said that had there been nothing beneficial in rejecting milk banks except 'adopting the more cautious' approach, we should have rejected establishing them. ${ }^{71}$

Because of this strong opposition from different scholars, the fatwa of al-Qaradāwī did not gain collective support from either IOMS or IIFA. During the 1983 session of the IOMS, the overwhelming majority of the participants agreed on discouraging milk banks in the Muslim and Arab world. However, they added, in case of apparent necessity, strict procedures should be followed, such as writing the name of the donating woman on each bottle, making a detailed registry including the name of the donating woman and the name of each baby who benefited from the milk, and giving this information to the families of both the woman and the baby. ${ }^{72}$ During the 1985 session of the IIFA, the text of the collective fatwa issued in the name of IIFA, as mentioned above, agreed with the opponents rather with al-Qaraḍāwi .

\section{Second context: unequivocal advocacy concerning Muslim minorities in the West}

Although they were relatively few in number compared to the opponents, al-Qaradāwī did not lack physicians and religious scholars who supported his fatwa during the discussions of the IOMS and the IIFA. The main proponents during the 1983 session of the IOMS were the physician Khālid al-Madhkūr and the late Egyptian scholar 'Abd al-Latif Hamza (d. 1985), state Mufti of Egypt during the period $1982-1985 .^{73}$ During the 1985 session of the IIFA, the fatwa was advocated by two members; the Syrian scholar, Muștafā al-Zarqā and the Iranian scholar, 'Alī al-Taskhīiñ. ${ }^{74}$

\footnotetext{
${ }^{70}$ Qaradāghī, op. cit. note 63, pp. 473-474.

${ }_{71}$ Majallat, op. cit. note 48, p. 420.

${ }^{72}$ Bār, op. cit. note 60.

${ }^{73}$ Qaradāghī, op. cit. note 63, pp. 468-469.

${ }^{74}$ Majallat, op. cit. note 52, pp. 415-416, 418-419.
} 
Each of these religious scholars advocated al-Qaradāwī's fatwa for specific reasons. Just to elaborate on the Shī'i standpoint in this regard, we refer to the Iranian Shī'ī scholar, 'Alī al-Taskhīrī, who is an adherent of the aforementioned Ja'farī school. Al-Taskhīrī advocated the fatwa of al-Qaradāwī on the basis of the first argument. That is because the minority opinion among the Sunni scholars adopted by al-Qaradāwī agrees with the Ja'fari school which also stipulates that the baby should suckle the milk directly from the woman's breast, otherwise the feeding does not constitute real radā and thus does not institute kinship. ${ }^{75}$

Despite the credibility of these proponents as wellknown religious scholars, they could not change the collective standpoint adopted by the IOMS and the IIFA. Thus the main trend remained opposing the establishment of milk banks in the Muslim and Arab world.

However, the fatwa of al-Qaradāwī issued in 1983 had to wait almost two decades before it could enjoy the unanimous advocacy from the members of the European Council for Fatwa and Research (ECFR) in 2004. Following the general tradition of religio-scientific institutions when they discuss biomedical ethical issues, the ECFR sought the expertise of the biomedical scientist, the Germany-based Syrian scholar Muhammad al-Hawwārī (PhD in pharmacy) who submitted a paper on this topic to the ECFR. Al-Hawwārī played the same role as that of al-Bār during the 1985 session of the IIFA. However, unlike al-Bār, al-Hawwārī was in favour of milk banks. ${ }^{76}$

Al-Hawwārī was aware of all earlier discussions including the paper of his counterpart al-Bār and the arguments of previous proponents and opponents of al-Qaraḍāwī's fatwa. He started by refuting a number of al-Bār's arguments against milk banks, namely, the risk of disease transmission through milk preserved in these banks and the decline of the phenomenon of milk banks in Western countries. Al-Hawwārī stressed that milk preserved in these banks undergoes accurate medical checkups to make sure that the milk is free of any dangerous diseases such as AIDS or hepatitis. Further, in reference

\footnotetext{
${ }^{75}$ Ibid: 415-416. In response to a question I sent to the official website of the Lebanese Shī‘i scholar Muhammad Husayn Fadlallāh (http:// www.bayynat.org/) about milk banks, I got the answer, via an e-mail dated 26 March 2010, that establishing such banks is not prohibited. However, the fatwa stated that the acceptable argument here is the unknowable identity of the women donating milk. The fact that milk does not reach the baby's stomach through direct suckling from the breast, the fatwa added, cannot be used as an argument to justify establishing these banks because using such milk would still establish milk kinship. So, it seems there is also a certain degree of diversity within the Ja'fari school at least on the level of the acceptable arguments in this issue.

76 Muhammad al-Hawwārī. Bunūk al-Ḥal̄î wa 'Alāqatuhā bi Ahkām al-Rada': Dirāsa 'Ilmiyya Fiqhiyya. Scientific Review of the European Council for Fatwa and Research 2005; 6: 25-31.
}

to al-Bār, al-Hawwārī argued: 'Contrary to some people who said that the number of these banks is decreasing and shrinking, I assert that they are widespread in the Western world.' As evidence, he mentioned that France has about twenty milk banks in addition to other banks in Germany, Europe at large and the United States. ${ }^{77}$

Despite their apparent discrepancies, the standpoint adopted by al-Bār in 1985 and that of al-Hawwārī in 2004 are both plausible if read within their proper context. As mentioned earlier (section 1), the number of milk banks had shrunk dramatically in the 1980s with the advent of AIDS because of people's concern about possible infections. This explains al-Bar's standpoint which he based on personal contacts and face-to-face information from colleagues in the United States during his visit in January $1983 .{ }^{78}$ However, al-Hawwāri spoke about the situation in the 21 st century when milk banks started thriving considerably all around the world.

Apart from al-Bār's position, al-Hawwārī criticized the aforementioned fatwa of the IIFA because it neglected the situation of the growing number of Muslims living in the West where such banks represent a common reality. Thus, 'It is inevitable to reinvestigate this issue in the light of the new findings in a bid to come up with a religious ruling that coincides with the situation of Muslims in the Western world', al-Hawwārī argued. The 'new findings' referred to here, which necessitate revising the 1985 fatwa of the IIFA, can be summed up in two main points. ${ }^{79}$

First, discussing this issue as far as it concerns Muslim minorities living in the West is not a theoretical investigation any more, a fact which creates a different context from that of the 1985 discussions among the IIFA members. Numerous milk banks have already been established in Europe and the United States. Thus the question, 'is it permitted to establish milk banks?' no longer has any relevance in this new context. This point was also clearly stated by al-Qaradāwī later in a TV interview entitled 'the particularities of the European Islam (Khusūsiyyāt al-Islām al-Ürubbì)' on al-Jazeera Channel (Qaradāin̄în, Yūsuf al-, 2004).

Second, the arguments of al-Qaradāwī used in his fatwa in favour of milk banks (section 3. One Text: The Fatwa in Focus) cannot be challenged any more on a juridical basis. Milk banks established in the West do not keep a detailed registry of the donating women, the name of the receiving babies or the amount of milk given to each baby. Thus, the element of doubtfulness (shakk) is clear in this case, in which such practice would not institute kinship that prohibits marriage in Islam according to

\footnotetext{
77 Ibid: $26-29$.

${ }^{78}$ Bār, op. cit. note 60 , p. 394.

${ }^{79}$ The information below is mainly based on notes I took while attending the ECFR $12^{\text {th }}$ session, held in Dublin during the period 31 December 2003 to January 2004, which discussed the issue of milk banks.
} 
the majority of Muslim jurists. The counter-argument of the opponents was always that this doubtfulness is not a reality because there are still no milk banks in the Muslim and Arab world. With the numerous milk banks established already in the West, this counter-argument no longer applies.

On the basis of these 'new findings', the members of the ECFR agreed unanimously to revise the previous fatwa of the IIFA, justifying this revision by saying that it was due to the change in the criteria on which the decision of the International Islamic Fiqh Academy was based, particularly those concerning Muslims residing in Western countries, where milk banks have existed for a long time and where they increase in number and spread from one country to another; and due to the increase in the number of Muslims residing in the West and the absence of identified wet nurses, which is unlike the case in the Muslim world. ${ }^{80}$

The text of the ECFR fatwa was published in Arabic in the Scientific Review of the European Council for Fatwa and Research and online via the website of the ECFR and in English via www.islamonline.net. The fatwa was also discussed in one of the episodes of the well-known TV programme, also among Muslims living in the West, 'Al-Sharī'a wa al-Hayāh (Islamic Law and Life)'. Al-Qaradāwi was the guest of this episode broadcast on 11 January 2004, a few days after the closure of the 12th session of the ECFR where the council had discussed human milk banks. As an indication of the validity of this fatwa, particularly for Muslim minorities in the West, the episode was entitled 'the particularities of the European

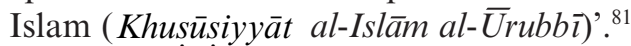

Information is still very scarce about the probable influence of this fatwa on Muslims in general and especially those living as religious minorities in the West; and no anthropological or empirical studies have been conducted to investigate its influence. However, a hot debate was triggered by the end of 2007 in Egypt, when the National Research Centre expressed its intention to establish the first human milk bank in Egypt. In response to people's concern that the idea might be incompatible with the rulings in Islamic Law concerning $\mathrm{rad}^{6}{ }^{6}$ (fosterage), officials said that milk given to babies will be 'mixed' so that no baby will not receive five complete nursing sessions from one woman. This is of course a reference to the argument upon which the fatwa of the

\footnotetext{
${ }^{80}$ Intifă' ${ }^{\circ}$ op. cit. note 44, pp. 4-5, p. 464; European Council for Fatwa and Research. 2004. Breastfeeding. Available at http:// www.islamonline.net/servlet/Satellite?pagename=IslamOnline-EnglishAsk_Scholar/FatwaE/FatwaE\&cid=1119503549312 [Accessed 02 Aug 2008].

${ }^{81}$ Yūsuf al-Qaradāwī. 2004. Khușūsiyyāt al-Islām al-Ūrubbī. An episode of the TV programme Al-Sharī'a wa-l-Hayāh broadcast on al-Jazeera Channel on 11 January 2004.
}

ECFR was based. ${ }^{82}$ In the light of this debate, the website www.islamonline.net investigated the viewpoints of different religious scholars and many of the proponents referred to the arguments used in al-Qaradāwì's fatwa and that of the ECFR. One of the readers who commented on the website's report referred specifically to the fatwa of al-Qaradāwī in favour of milk banks. Would this mean that the fatwa endorsed specifically for Muslim minorities living in the West could have an influence on Muslims living in the Muslim and Arab world as well? Only future developments will answer this question.

\section{CONCLUSION}

The aforementioned discussions on human milk banks demonstrate more than one point whose validity holds true for the field of Islamic biomedical ethics in general.

First of all, this subject shows clearly that scientific technologies produced in the West, deemed by different voices in the West as inherently beneficial, are not by default perceived in the same way in other cultures. As Marcia Inhorn, the well-known American anthropologist put it:

Local considerations, be they cultural, social, economic, or political, shape and sometimes curtail the way that Western-generated scientific technologies are both offered to and received by non-Western subjects. ${ }^{83}$

I would just add 'religious' to the list of considerations named by Inhoorn. Although the religious scholars quoted in this article concede benefits in milk banks, a considerable number of them could not permit them in the Muslim and Arab world because of religious objections.

Another important note in this regard is that Muslim scholars, bearing in mind the multidimensional character of these issues, are now inclined to discuss such issues collectively rather than individually. Furthermore, religious scholars seek the advice of physicians and scientists who usually play an important role in formulating the final fatwa to be issued, as was the case with al-Bār in the IIFA and al-Hawwārī in the ECFR. That is why the

\footnotetext{
${ }^{82}$ Inshā’ Awwal Bank li Halīb al-Ummahāt fì Mișr. 2007. Al-Bayān, 11 December, Available at http://www.albayan.ae/servlet/Satellite? $\mathrm{c}=$ Article $\&$ cid $=1195398724437$ \& pagename $=$ Albayan $\% 2 \mathrm{FArticle} \%$ 2FFullDetail [Accessed 02 Aug 2008]. For a concise survey on the opinions of the proponents and opponents of establishing milk banks in Egypt among the scholars of al-Azhar, where all the above-mentioned arguments and counterarguments have been repeated, see Hiba Hasan. Bunūk al-Albān bayn al-Halāl wa al-Ḥarām. Al-Tasawwuf al-Islāmī 2007; 347: 38-40.

${ }^{83}$ Marcia Inhorn. Making Muslim Babies: IVF and Gamete Donation in Sunni versus Shi'a Islam. Cult Med Psychiatry 2006; 30: 429.
} 
fatwas issued by institutions such as the IIFA and the ECFR usually enjoy great weight and wide acceptance among Muslim scholars and the Muslim public as well. However, collective fatwas issued by these institutions remain in principle open to further investigations and potential revisions from individual scholars or from other juristic institutions.

Finally, despite the crucial importance of the classical opinions within the Sunni and Shî'i schools of law, they are not the only element upon which the fatwas of contemporary Muslim scholars are based. Biomedical information and social realities, for instance, could be decisive factors in this regard, as was the case with the difference between the context in the Muslim world and that of Muslim minorities living in the West.

\section{Acknowledgements}

An earlier version of this paper was read during the workshop on 'Islam and Medical Ethics' held by the University of Nijmegen during the period 5-6 April 2007. I would like to thank Prof. Evert van Leeuwen (Nijmegen University, the Netherlands) for inviting me to this workshop and Dr. Rainer Brömer (Fatih University, Turkey) for his helpful criticisms of an earlier draft of this paper. Finally, my thanks go to the two anonymous reviewers who provided me with useful suggestions and criticisms.

Mohammed Ghaly is a graduate of al-Azhar University in Egypt and currently an assistant professor of Islamic studies at Leiden University, the Netherlands. After completing his book Islam and Disability (Routledge, 2010), Ghaly is doing research on Islamic bioethics with the main focus on the interplay of Islam and the West. 